\title{
Lung Cancer pT0 TNM Finding v6 and v7
}

National Cancer Institute

\section{Source}

National Cancer Institute. Lung Cancer pTO TNM Finding v6 and v7. NCI Thesaurus. Code C60966.

Lung cancer without any evidence of a primary tumor. (from AJCC 6th and 7th Eds.) 